Article

\title{
Ghosts in the Closet: Catastrophizing and Spectral Disability in Anne Charlotte Robertson's Apologies
}

\author{
Taryn Marie Ely
}

Visual and Cultural Studies, University of Rochester, 317 Lattimore Rd, Rochester, NY 14627, USA; taryn.m.ely@gmail.com

Received: 9 August 2019; Accepted: 22 October 2019; Published: 24 October 2019

\begin{abstract}
Anne Charlotte Robertson, who died in 2012, was a Super 8 experimental filmmaker whose primarily diaristic films record her experience with a diagnosis of manic depression and the corresponding nervous breakdowns. This article specifically addresses Robertson's film Apologies (1983-1990), which features $17 \mathrm{~min}$ of the filmmaker apologizing to the camera for everything from drinking non-organic coffee to returning her camera a day late to her eventual nervous breakdown in the final scene of the film. Beginning with the psychological concept of catastrophizing, this paper shows how Robertson's film engages with larger contemporaneous philosophical conceptions of disaster, or apocalypse, and its corresponding temporality. Drawing upon Jacques Derrida and Maurice Blanchot, mental disability is shown to be more thoroughly understood through shifting and multiple temporalities, termed as 'spectral disability' within this paper. Apologies not only reveals the personally specific details of Robertson's experience and identity, but also responds to a larger history of representing madness in photography and film. Robertson's engagement with the moving image is not only related to philosophy and history, but predates similar techniques devised in psychology as well. Ultimately, through disability theorist Rosemarie Garland-Thomson's concept of misfitting, this paper explores how Apologies exposes the creative possibilities of mental disability.
\end{abstract}

Keywords: Anne Charlotte Robertson; experimental film; diary film; disability studies; history of psychology; catastrophe

I'm sorry for not being more active politically. Is exposing social behavior, such as apologies, political?

Anne Charlotte Robertson, Apologies (1983-1990)

The problem of anxiety neurosis may be epitomized metaphorically as an overactive "alarm system".

Beck (1976)

The Super 8 experimental filmmaker Anne Charlotte Robertson made over 30 films between 1976 and 2001. Prolific while she was alive, Robertson's financial troubles and frequent hospitalizations often kept her from gaining greater traction in the world of experimental film. Although she previously screened her work at well-known film and video art venues, it has only become more recognized in recent years, especially since the Harvard Film Archive's screening at the New York Film Festival in 2013 (Dargis and Scott 2013). Since then, her work has been included in screenings such as the 2014 London's Anxiety Festival. Only in recent years have scholars and artists even begun to grapple with the immense contributions of Robertson's diaristic forms. The artist refined her intimate, personal, diaristic works while attending the Massachusetts College of Art where she studied under filmmaker Saul Levine, whose body of work also engages with an intimate, autobiographical form. 
Among the many autobiographical experimental filmmakers, Robertson's films stand out because their subject matter is often the filmmaker's own experiences with mental illness. Her films explore nervous breakdowns and her life before and after multiple hospitalizations. In addition to her nervous breakdowns, she records her daily struggles with weight and finding her future husband, but also everyday pleasures such as gardening, pets, and her extended family. Her most recognized works come from the autobiographical experiment Five Year Diary, which consists of over $36 \mathrm{~h}$ of film made between 1981 and 1997, much of which has recently been preserved by the Harvard Film Archive. Representative of her practice, Five Year Diary includes original images as well as multiple layers of sound recording. When presenting her films at screenings, Robertson also added another layer of sound through in-person narration and decorated the screening space with personal childhood objects. ${ }^{1}$ These practices speak to how Robertson's work attempts to reveal the complicated nature of subjectivity.

Robertson is far from the first to complicate subjectivity through autobiographical or diary filmmaking. Avant-garde film pioneer Jonas Mekas worked extensively in the mode that he called 'diary'. Although not necessarily a chronological recording of events, Mekas's epic Diaries, Notes, and Sketches (1969), for example, combines quotidian life with a personal voiceover by the artist that reflects on his experience as an immigrant. Many avant-garde artists worked with some form of home movie, or a filming of the everyday, often adding voiceover as a key element of their practice. The diary film became a means of reflecting on the nature of events and their temporality. Rather than simply record a chronology, the diary film complicates a simple notion of linear temporality. The combining of disparate images and the weaving together of image and voiceover create what Margo Culley (1985, p. 20) refers to as a "continuous present". The past and future are reflected upon through the present in the diary film. In News from Home (1976), Chantal Akerman uses mostly static shots of New York City combined with voiceover of the letters that she wrote to her mother in France. The time between letters creates temporal gaps that reflect on the spatial gap Akerman experienced when away from home. This play with temporality figures strongly in much of Robertson's work as well. Her extensive use of voiceover reflects on both past and future within a continuous present.

In the 1970s, feminist artists would take up the autobiographical or diary form by turning the camera on the body. As the body became an important subject for feminists, Carolee Schneemann in her film Fuses (1967) recorded her and her partner in an explicit act of lovemaking. Participating as both the director behind the film and the body on the screen, Schneemann creates a unique and potentially subversive cinematic relationship to the female body, which Shana MacDonald (2007, pp. 67-71) refers to as erotic self-portraiture. Throughout her filmmaking practice, Anne Charlotte Robertson continually turns the camera on herself and on her mental disability. By turning the camera on herself and using the diary form's mode of continuous presence, she complicates the nature of subjectivity as it relates to mental disability.

Film critics often emphasize that Robertson regarded filmmaking as what saved her life. In interviews, she suggested that the very act of filming and going to film school gave her something to do and, she felt, reduced the frequency of her mental breakdowns (MacDonald 2014, pp. 25-26). Additionally, the films and their multimedia form gave Robertson a new means of engaging with her experience of mental disability. In a screening program for London's 2014 Anxiety Festival, which featured Robertson's work, Lisa Blackman (2014, p. 8) notes how "common narratives tend to focus on the ordinariness of mental ill-health [or] recovery". But Robertson's multiple layers of visual and auditory documentation expand the experience of mental disability to include a nuanced understanding of what it means to experience the "catastrophe" of a nervous breakdown. Coated with additional layers of sound recording that take on the tenor of melancholic insight, the films provide

1 Scott MacDonald wrote of a screening of Five Year Diary at the American Museum of the Moving Image in 1988, where the nearly 40-h long film was screened "half-hour by half-hour" over the course of a week. See (MacDonald 2005, p. 206; 2014, p. 11). 
a documentation of multiple subjectivities within a single subject, which complicates the notion of film's linear temporality and offers a fuller picture of a living being. In addition to the films being a therapeutic outlet for Robertson, her body of work offers a singular view into what it means to live with mental disability.

More than being a documentation of illness or a voyeuristic look into her condition, Robertson's work is an example of the creative possibilities of mental disability and how an individual creatively copes with their misfitting in the world (Garland-Thomson 2011, pp. 591-609). Misfitting is defined by Rosemarie Garland-Thomson as an incongruent fit between a person and their environment, such that a person would need to creatively problem solve to gain access to the same privileges as nondisabled individuals. These creative strategies emerge through the way Robertson approaches and formalizes her films' content. Mental disability often misfits with the common ways in which information is interpersonally communicated or how stories are commonly told. Throughout Robertson's work, incongruities between image and sound or incongruities in the image's focus emphasizes the frustration of a misfit. Through filmic means, Robertson creates a strategy for communicating her mental distress by amplifying the incongruencies between the film, herself, and her environment. Further, her creative strategies reflect Rosemarie Garland-Thomson's observation that "misfitting can yield innovative perspectives and skills in adapting to changing and challenging environments" (ibid, p. 604). This perspective transforms the above epigraph by Aaron Temkin Beck, providing instead a feminist, materialist disability understanding of panic disorder. Instead of anxiety being formulated as an overactive or defective alarm system, the impairment of panic can be seen as a highly sensitive alarm system that identifies potential larger societal incongruencies or misfits. Giving serious attention to Robertson's creative adaptation, this essay uncovers how her work is both intensely specific, responding to her particular experience of mental disability, and social, in the ways her films respond to the history of medicalized treatment and representation of mental disability. In creatively navigating her personal world, Robertson inadvertently speaks back to the history of psychiatric and psychological documentation in forms that point to their limits and shortcomings.

This essay engages specifically with Robertson's film Apologies made between the years of 1983 and 1990. Although not a part of Five Year Diary, this 17-min film is reflective of central concerns present across the artist's larger body of work. In Five Year Diary, Robertson uses her talent for framing an image to record everyday events, such as tracking her diet or having a brief affair with another video artist. In The Definitions of Fat and Thin (1981), she combines performative elements of reading dictionary definitions with footage of the meals that she cooks and the food that she is tempted to eat. In A Short Affair (and) Going Crazy (1982), she combines images and sound taken during a nervous breakdown precipitated by her lover leaving. A Short Affair also includes an additional layer of sound in which Robertson reflects on and interprets her experience of a nervous breakdown. The performative element and the delayed reflection on her actions are both significant parts of Apologies and Robertson's work in general. Performativity is foregrounded in Apologies much like in the short film Talking to Myself (1985), where the artist uses double exposure to diegetically have a conversation with herself. Her use of Super 8, although chosen for its affordability, gives a homemade, personal quality to the work. Here and throughout Robertson's practice, image and sound become layered to complicate and expand our understanding of mental disability and subjectivity.

Apologies explores Robertson's compulsive sense of guilt and the corresponding need to make apologies. Although the film deals with the quite serious subject of mental disability, the candidness of Robertson's self-exposure begets a playfulness and a sense of wit. The film consists of a play with multiple temporalities through editing both image and sound. The first nine minutes of Apologies cross cuts between scenes of Robertson apologizing and scenes of Robertson commenting on her apologies. In the apology scenes, she is off-centered within the frame, often not making direct eye contact. Her eyes are downcast as she recites her guilt. Other times, her lack of eye contact occurs because she is driving a car. These scenes are confessional, yet they take place in everyday settings. On the other hand, the commentary scenes show Robertson approaching the camera head on while expressing her 
distaste for her apologizing. She wears black clothing against a black background, making her face nearly all that is visible. As the film was made over the course of seven years, these two scenes were shot at different times, but in the film, cross-cutting places them in direct conversation with one another. As the film continues, the two distinct scenes and their disparate temporalities are merged and related.

In the second half of the film, time is further blurred together. Robertson adds a post-production voiceover to silent footage of herself in a mirror. At this point, the two temporalities come to occupy the same frame. In the following scene, the original sound only comes through in pieces and Robertson attempts to fill in the gaps with post-production lip-synching. The result is a greater and greater blurring of the different temporal versions of Robertson. The film ends with Robertson's nervous breakdown crosscut with more scenes of commentary to the camera and is complicated with additional voiceover. The consistent interplay between edited scenes and voiceover create a unique form of self-expression that corresponds to the nature of Robertson's apologies themselves.

Throughout the film, she apologizes for events that have yet to happen. This obsession with possible negative outcomes highlights a form of cognition known in psychology as catastrophizing, a foretelling of worst-case scenarios. Beyond simply illustrating catastrophic thinking, Robertson's film reveals the spectrality, a form of anachronistic haunting, inherent in the experience of catastrophic thinking. This sense of catastrophic spectrality allows Robertson to engage with time, history, and subjectivity. In so doing, Apologies highlights both a therapeutic means of coping with illness, but also a particular orientation to the self and to illness that allows for a more effective means of confronting personal, political, and social catastrophe.

In the field of psychology, the concept of catastrophizing is defined as a "tendency to magnify a perceived threat and overestimate the seriousness of its potential consequences" (Beck and Gellatly 2016, p. 441). The term catastrophizing was first coined in 1962 by Albert Ellis in his pathbreaking work Reason and Emotion in Psychotherapy. A break from psychoanalysis, this publication and his methods of "rational emotive behavior therapy" were some of the first sources to explicate the methods and research of what would later become highly influential on the psychological practice known as cognitive behavioral therapy (CBT). In his text, Ellis perceives certain habits in thinking as irrational and sought to identify ways that individuals could challenge these "irrational" thoughts with neutral self-talk. He writes:

More specifically, he should perceive his own tendency to catastrophize about inevitable unfortunate situations-to tell himself: 'Oh, my Lord! How terrible this situation is; I positively cannot stand it!' —and should question and challenge this catastrophizing, and change his internalized sentences to: 'It's too bad that conditions are this frustrating. But they won't kill me; and I surely can stand living in this unfortunate but hardly catastrophic way'. (Ellis 1975, p. 71)

Ellis suggests that an individual must step outside their own thought processes to perceive them as "irrational," and then, in what appears to be a slight antagonism, challenge those thoughts with the voice of psychological reason. Ellis proposes that patients learn to adopt a second voice in the form of psychological reason and the methods he discusses. This second voice is similar to Robertson's multiple layers of sound or her editing between two different temporalities. In psychological discourse, the hope is that this second voice will gradually come to take the place of the first, so that "rational" thought processes become automatic. Apologies shows how the second voice spectrally exists alongside the first, and sometimes alongside a third, or even forth, voice. Ellis recognizes that compared to the practice of Freudian psychoanalysis, his methods are seen as superficial, as they do not necessarily address possible unconscious forces, but instead focus on the visible, or surface level, information provided directly by the patient (ibid, pp. 348-51) Despite going against decades of Freudian doctrine, his work, especially his understanding of misperceptions in thought, became highly influential in CBT and was taken up by psychologist Aaron Temkin Beck, who continues to research the broad applicability of catastrophizing. 
Although the use and relativeness of Freudian concepts never completely disappears with CBT, consciousness gains a position as the primary plane on which the therapist operates. Beck writes: "Cognitive therapists operate through the conscious part of the apparatus; that is, they try to strengthen the conscious part, so that it gets greater leverage or greater control over the nonconscious information processing" (Alford and Beck 1997, p. 132). The binary of conscious and unconscious is still present in CBT. However, in the case of CBT, there is a desire to make the conscious mind more apparent to the individual. In describing the application of catastrophizing to anxiety, Aaron Beck writes: "Catastrophic misperceptions of interoceptive cues occurs in panic disorder according to automatic (unconscious) as well as conscious processes. Panic patients are predicted to display this specific cognitive content during panic attacks" (ibid, p. 100) Therapists drop the distinction between "rational" and "irrational," but their language still maintains a right/wrong binary. Beck calls them "catastrophic misinterpretations," while Judith Beck refers to "consistent errors in ... thinking" (Beck 1995, p. 118).

These supposed errors occur when a person interprets either an external or an internal stimulus in a way that predicts or foretells a worst possible outcome in the form of "physical, mental, and behavioral catastrophes" (Beck and Gellatly 2016, p. 442). The classic example of applying catastrophizing to a panic disorder is the interpretation of chest pain. Resham Gellatly of the Aaron Temkin Beck Psychopathology Research Center writes: "A characteristic belief of this disorder is that chest pain is a sign of an impending heart attack. Beck observes that panic patients have fixed focus on the symptoms and catastrophic beliefs, which renders then unable to stop anxiety before it escalates into panic" (Beck and Gellatly 2016, p. 442). The person becomes highly fixed on the stimuli and their interpretation. The concept of predicting a possible future is emphasized by Judith Beck: "When people predict the worst, we call it fortune-telling or catastrophizing-believing that a catastrophe might happen" (Beck 1995, p. 120). The fortune-telling belongs to the future, but it is also recognized that these habits of catastrophic thinking often have a basis in an individual's past experience. Gellatly and Beck observe: "Educating troops and veterans about brain damage may have potentially adverse consequences. Individuals who are made aware of the symptoms of [traumatic brain injury] may become hypervigilant and catastrophically interpret benign sensations" (Beck and Gellatly 2016, p. 445). This example demonstrates that past information or experience also plays a part in the foretelling of the future and the prediction of future catastrophes. These temporalities are fused, mixed, and rearranged. Time is not a linear narrative. Instead, multiple temporalities merge in a single subject to produce the ingredients for catastrophic thinking. Starting in the 1960s and continuing into the present, Aaron Temkin Beck and many other researchers have applied catastrophic thinking to anxiety, depression, obsessive compulsive disorder, posttraumatic stress disorder, phobias, pain, and traumatic brain injury (ibid.). The treatment for catastrophizing includes helping individuals develop new means of interpreting and changing beliefs about internal and external stimuli.

Catastrophizing, and thus temporality, are central components in Robertson's film. In Apologies, she compulsively apologizes for everything from the lighting of the film to having a nervous breakdown in the last scene to drinking coffee to apologizing for apologizing. Robertson addresses the camera, and her future audience, as she documents her constant need to apologize. She foretells the audience's displeasure at every aspect of the film and in every aspect of her personal life. She apologizes in a present tense, but, of course, the film (and thereby the apology) can only be received by the audience in an undetermined future. At one point, the underexposed or out-of-focus image is a stimulus that triggers a belief that a viewer will be upset by the imperfect image, which then necessitates a premonitory apology. Each external physical stimulus or internal thought or emotion triggers a belief of a worst possible outcome that would then require an apology. The internal stimuli could also be identified as Robertson's feelings of guilt, which, without any basis in the immediate present, cause Robertson to search for events or circumstances to which she can assign her guilt. This blurring of the distinction between her internal thoughts and emotions and the outside world sometimes appear to trap her in an endless cycle. Guilt breeds apology, which breeds guilt, which breeds apology ad infinitum. 
The ongoing apologies illustrate her turning the most quotidian ideas into an ongoing personal catastrophe that conflates past and future, as well as inside and outside. The catastrophe is that her audience will be offended or that children will starve because she spent possible donations to world hunger on another pack of cigarettes. Robertson seems certain that not growing her own coffee and instead drinking non-organic coffee will offend or harm someone, and she has to apologize for it. She apologizes for possibly locking someone out of the public bathroom to record film. She imagines a person on the other side of the door waiting to confront her with their anger. While the thinking that accompanies these apologies foretells the future consequences of her actions, they may also be influenced by past experience. For example, Robertson apologizes multiple times for returning the camera late and she apologizes to the people in her films who did not want to be there. In an interview, she states: "In fact, that first [recorded] breakdown occurred shortly after a person at school threatened he'd call the cops and take the camera away from me" (MacDonald 2014, p. 26). It appears that these experiences and threats remained with her. They were carried into the present and into these possible catastrophic futures. The combination of Robertson's film form and content demonstrates how time is never solely of the present in catastrophic thinking.

This mixing of temporality is not solely a preoccupation of psychology. These same aspects of time abound in philosophical discourse. Foretelling of the future is a primary preoccupation in Derrida's discussion of Kant's critique of an apocalyptic tone in philosophy. Central features of what Derrida identifies as an apocalyptic discourse have deep resonance with Robertson's work. Derrida addresses how an apocalyptic document includes "prediction, the fact of telling, foretelling, or preaching the end, the extreme limit" (Derrida 1982, p. 80). Kant addresses those who use an apocalyptic tone to say that they signal the death of philosophy due to the mystagogic revelatory nature of the tone, or a tone that renders philosophy impotent. If a mystic can foresee the truth, why would we need the philosopher? Kant ultimately negotiates a deal with those he criticized in order to save philosophy. However, Derrida confronts Kant's own premonitions when he states: "But if Kant denounces those who proclaim that philosophy is at an end ..., he has himself, in marking a limit, indeed the end of a certain type of metaphysics, freed another wave of eschatological discourses in philosophy" (ibid). In supposedly saving philosophy with his agreement with the mystagogues, Kant himself partakes in discursive fortune-telling by suggesting the end of a type of metaphysics instead of philosophy.

Derrida acknowledges his own participation in apocalyptic discourse with the theoretical approaches of deconstruction. In fact, he advocates for the apocalyptic discourse due to its ability to get around censorship, or to transgress established boundaries. "By its very tone, the mixing of voices', genres, and codes, and the breakdown of destinations, apocalyptic discourse can also dismantle the dominant contract ... It is a challenge to the established admissibility of messages and to the endorsement or the maintenance of order of the destination" (ibid, p. 89). The mixing of the preestablished modes can aid in the dismantling of disciplinary boundaries or boundaries of thought. Robertson herself mixes voices in the form of her multiple sound recordings. The voices are not only hers, but, like the veteran educated about traumatic brain injury, the catastrophic voices contain the information or expectations of others. There is also the mixing of time, which challenges the effectiveness of linear narrative and the process of revealing information. Robertson conflates genres, specifically diary and documentary, by being both the documented object and the author of the film. The mixing of messages challenges psychological methods, such as cognitive behavioral therapy and its modes of communication. While the filmmaker documents her own apocalyptic expression and her own possible moment of catastrophe, the nervous breakdown, her methods of doing so push up against the norms of psychological discourse through a use of spectral temporality.

The apologies seen through the lens of the psychological concept of catastrophizing suggest a mixture of past, future, and present. The past always threatens the present moment with its reemergence in the future. The memory of an undesirable event from the past threatens the future. It is the dead histories that could return as ghostly apparitions in the future. While catastrophizing itself takes on these spectral qualities, the formal elements of Robertson's film take time further out 
of joint. Robertson's Five Year Diary films lay out a chronological history by indicating historical dates in the titles. However, although Apologies follows a diaristic mode of address, the actual dates of occurrence that could typically be pointed to in a diary are rendered unreadable for her viewer. Robertson's apologies are organized into scenes or vignettes, and at the same time, these scenes consist of highly edited fragments. We see her in a bathroom or a park or in her car where she recites a series of apologies, but the scenes themselves consist of edits. We have no sense of continuity from one scene to the next. It is uncertain which apologies came first, second, or last. Causing further ambiguity of time is the fact that the film was made over the course of seven years. Additionally, these scenes in quotidian places are intercut by a series of performative announcements by Robertson. In these series, Robertson wears all black against a dark background, her long hair swaying as she swiftly approaches the camera with more apologies or commentary on apologies that often took some form of an apology. Her figure itself is ghostly in these scenes. Her face is nearly all that is visible in any detail with a single source of lighting illuminating the space. Her voice is a shaky moan, almost that of a ghost. Through this engagement, Robertson's sense of self is figured as, what Jacques Derrida termed, 'hauntology'. ${ }^{2}$ The very ontology of the self is a mix of varied temporal experiences.

Sound throughout the film also renders the viewing experience as highly spectral. Derrida, quoting Shakespeare's Hamlet, suggests that where specters exist "'time is out of joint': time is disarticulated, dislocated, dislodged, time is run down, on the run and run down, deranged, both out of order and mad" (Derrida 1994, p. 18). Robertson separates the joints of time by adding multiple layers of sound. One source is the original sound which, as Robertson's Super 8 camera has an external corded microphone, is often out of sync with the images. There is an uncanny double, a ghostly double of the voice that disarticulates the present moment. Apologies complicates this first uncanny layer with a second track of audio that Robertson applies as commentary. In one instance, the microphone does not work in the initial filming. Robertson attempts to fill in the gaps of sound by lip-syncing, but she does so poorly and apologizes for it. In these scenes, the original sound occasionally breaks through, creating difficulty in deciphering what is original and what is added in post-production. The voices become multiple, and their multiplicity is temporal. The madness of time becomes its multiplicity of past and future.

Finally, Robertson uses these disjointed forms of commentary to make her viewer aware that they will see her having a nervous breakdown at the end of the film. In one of her first approaches to the camera, she says: "I'm sorry I have a nervous breakdown in the last scene and I take my clothes off, which is ridiculous. And I'm sorry I'm ridiculous". After revisiting the ghosts of her past, Robertson goes back in the time of the film to edit in an apology for our future experience. Derrida states: "The animated work becomes that thing, the thing that, like an elusive specter, engineers a habitation without proper inhabiting, call it a haunting, of both memory and translation" (ibid.) Robertson's voice that warns us of her future nervous breakdown does not properly inhabit a space in the film with a kind of linear temporality, but instead haunts it through the memory of breakdown and her interpretation of the film's documentation.

This fragmented, dislocated time is itself spectral. However, spectrality is not only reserved for the film. Spectrality is also a useful mode of understanding the visibility of mental disability. The history of mental illness includes a search for its visibility through photography and early technologies of film. The historical relationship between medicine and cinema has been well-documented in the fields of visual culture, disability studies, and aesthetic philosophy. ${ }^{3}$ These historical documentations have typically been still photographs or straightforward cinematic documentation that aim to grasp physiological differences in the movements or features of mentally disabled people. In the assessment of photographs such as Jean-Martin Charcot's pictures of hysterics, it has been recognized that these

2 Derrida's concept of hauntology is elaborated in Specters of Marx, see (Derrida 1994). Lisa Blackman has previously made an association between Robertson's work and the concept of hauntology, see (Blackman 2014, p. 8).

3 For example, see (Agamben 2000; Cartwright 1995; Gilman 1982; Hall and Siebers 2015). 
documents now tell more about the photographer than the actual disabled person. One reason for this is that little information is known about the individuals who posed for these photos. Rather, these documentations tell of physicians' interpretations of symptoms and the anxiety surrounding the failure "to gain access to knowledge of the bodies that populate their field" (Cartwright 1995, p. XIV). In her book Screening the Body, Lisa Cartwright, for example, rehearses this history by describing the physicians' attempts to record every seizure, which never proved easy considering the hindering physicality of early technology. As a result, neurologists resorted to forcing patients to exhibit symptoms through "mimed or mechanically induced expression" (ibid, p. 61). Even when physicians were able to capture a seizure on film, they would often only roll camera for the most dramatic moments and stopped filming during less visible expressions of seizure (ibid, p. 59). The physicians move farther away from the actual patient experience through the induction of artificial symptoms and by interpreting the importance or unimportance of particular symptoms during the research process. In addressing neurological film motion studies, Cartwright identifies how these attempts to capture visibility are no doubt wholly inadequate with regard to the accumulation of information regarding the patient. Instead, "the image increasingly becomes the site of a certain professional anxiety" (ibid, p. XIV). The visual semiotics used by neurology and psychology prove to be a misfit with the patients that they study, causing the image to always signal its own inadequacies. What leads up to or what follows the patient's "symptoms" is eclipsed from filmic documentation as physicians apply their own temporalities and other interpretative schema onto their object of study. A diary can be seen to stand in direct contrast to this practice, as Robertson often documents what appears to be mundane or ordinary moments that show no obvious sign of drama. But through a spectral notion of disability, these "non-dramatic" moments take on a life for the future or prove to be a haunting from the past, which play a significant role in mental disability.

The struggle not only to find literal visibility, but also political visibility, has been a common topic for recent scholars writing on mental disability. Considering the term 'psychosocial disability,' Cal Montgomery states: "I do think we need a way of talking inclusively about people for whom access to human interaction is problematic" (Price 2013). Montgomery's assessment of the problematic nature of human interaction for the mentally disabled can be directly linked to Robertson's experience of an obsessive sense of guilt, which is manifested through a connection or lack thereof with others. Robertson's mismatched temporality and warnings to viewers offer a form of communication through an incessant need to interpret her behavior for an audience. Spectral temporality is a mode of communication for the disabled filmmaker. Additionally, in her article "Defining Mental Disability," Margaret Price describes the visuality of mental disability as apparitional:

Although it's common to describe psychosocial disabilities as 'invisible,' or 'hidden,' this is a misnomer. In fact, such disabilities may become vividly manifest in forms ranging from 'odd' remarks to lack of eye contact to repetitious stimming ... Like queerness, psychosocial disability is not so much invisible as it is apparitional, and its 'disclosure' has everything to do with the environment in which it dis/appears. (ibid, p. 304)

Mental disability, or what Price refers to as psychosocial disability, has a visibility that is dependent upon its social context. On the one hand, this could be in the form of an individual's level of comfort in an environment, but it could also be in the form of a social environment's interpretation and awareness of a disabled person's inherent diversity. As with the early film documentation of neurology patients, a fuller understanding of a person's disability is foreclosed by an interpretive schema enacted $a$ priori by those who surround the disabled person. Further, the visibility that Price identifies is typically glimpsed briefly and does not fully inhabit a moment. These features can be recognized in Robertson's shaking hands as she determinedly and forcefully attempts to light her cigarette, in her sometimes monotone voice, or in her closed-off body language in the last scene. It may be useful to see mental disability as spectral in order to attain a more comprehensive view of the experience. In discussing the ways in which we might articulate such disparate texts together such as Shakespeare and Marx, 
Derrida writes: "To maintain together that which does not hold together, and the disparate itself, the same disparate, all of this can be thought only in a dis-located time of the present, at the joining of a radically dis-jointed time, without certain conjunction" (Derrida 1994, p. 17). Likewise, to hold together the disparate experience, temporality, and spatiality of mental disability, time must be out of joint. To hold together and make sense of the ticks, gestures, and spectral nuances, a complete picture requires more than a cause and effect or linear chronology. Just as Derrida suggests that an apocalyptic discourse can get past censorship and bridge boundaries, Robertson's approach to catastrophes and time move past her unproductive experiences of psychiatry, the pantheon of mental and emotional reason, and show her filmic work to be a contributor to disability and aesthetic theory (Derrida 1982, p. 89).

In Apologies, and in this essay, these ideas culminate in what may be considered the film's actual catastrophe or disaster: the nervous breakdown. Although we are given notice from the very start that the last scene contains a nervous breakdown, voiceover commentary at the beginning of the final scene tells us "I'm sorry but this is the nervous breakdown". Without this commentary, it is not certain that the audience would register this scene as a nervous breakdown. The only thing that perhaps is different is that Robertson takes her clothes off, except for a pair of moon boots, which she says she's not sorry for wearing. The nervous breakdown is fairly unspectacular. There is no crescendo or outstanding feature. There is no dramatic emotional catharsis. The preconceived notion that nervous breakdowns are somehow hyper visible or audible is rendered false. Contrary to popular representations, these so-called catastrophes of mental breakdown are no more visible than the spectrality of any other moment of mental disability. Robertson's film, taken as a whole, allows viewers to see how breakdowns are made catastrophic by psychiatric or psychological interpretive schema. At the film's end, it becomes apparent that the catastrophe is that there is no catastrophe. In Robertson's real and cinematic lives, there is a haunting in advance of the disaster which never comes.

Even though the person having the breakdown experiences pain and being placed in a mental hospital and having one's civil rights taken away is disastrous, without the institution, there is no catastrophic event. The etymology of the word catastrophe suggests "overturning, sudden turn, conclusion" (OED Online 2018). The turn of events in a nervous breakdown is actually enacted through the discourse of psychology. Studies of the mind have aimed at identifying a point of change, whether it be trauma, the starting point of a seizure, or a psychotic break. The institution defines the break, as well as defining catastrophizing by translating a person's conscious mind into the discourse of psychology, or into a linear narrative with a clear beginning, middle, and end. The lived experience proves to be much more fluid, much more without "incident". Time, taken together, or all at once, not a particular turn or a rise and fall narrative, provide Robertson with a means of communication beyond the translation of herself that has been provided for her by the institution of psychiatry/psychology. She finds that all the moments are relevant and that disasters or catastrophes do not truly arrive.

Derrida suggests that while the apocalypse is to unveil truth, there is now an apocalypse of the apocalypse. He states: “Our apocalypse now: that there is no determination" (Derrida 1982, p. 94). The apocalypse is that there is no apocalypse. There will be no final determination or ultimate truth. For Robertson, there is no truth to be deciphered in the breakdown. There is no nervous breakdown to end all nervous breakdowns. This line of thought is also present in Maurice Blanchot's The Writing of the Disaster. Blanchot's disaster is one that is perpetually situated in the future, but at the same time will never arrive. Blanchot relates this disaster that is always imminent but never present to the Other, which threatens subjectivity. He states: "If the Other is not my enemy, then how can he become the one who wrests me from my identity and whose proximity wounds, exhausts, and hounds me, tormenting me so that I am bereft of my selfhood and so that this torment, this lassitude which leaves me destitute becomes my responsibility?" (Blanchot 1995, p. 22). It is the proximity of the Other that threatens the very stability of the self. There is a relation here to Robertson's apologies: her guilt is her responsibility to the Other. As she apologizes, she pushes against the Other, which threatens her subjectivity or multiplies it into dispersed fragments. Nonetheless, her apologies remain constant and 
her selfhood remains intact as she repeats "I apologize" or "I would like to apologize". There is no experience of the death of the self, for death evades all experience. The disaster remains always in the future as she apologizes for the tragedy that might befall her. The disaster is that these disasters can never be known to happen once and for all. The self will be threatened in advance of the disaster that will never come. These disasters, the catastrophes, the unveiling apocalypses never arrive for certain. Instead, as Akira Lippit writes: "[They] haunt the present in advance" (Lippit 2012, p. 87).

Rosemarie Garland-Thomson's feminist materialist disability concept of 'misfit' provides a further means of understanding the impact of the self/other relationship as it plays out for Robertson. To fit or misfit in an environment materializes both the identity of the person and the identity of the environment through exclusion or inclusion, accommodation, or segregation (Garland-Thomson 2011, pp. 594-96). Additionally, whether there is a fit or misfit is also dynamic, constantly changing in one instance or another. Garland-Thomson argues that the temporal combination of all the instances of fitting and misfitting come to form our social and personal identity (ibid, pp. 595-96). The common occurrence of social and communicatory misfitting for the mentally disabled is related to Blanchot's Other, which 'wrests' us from our identity. Our identities are dynamic. For Robertson, piecing out and consolidating her identity through fits and misfits is a source of stress in her life. Her past experiences of misfitting haunt the future with a threat to her continuous sense of self. It is film, both its production and reception, that allow Robertson to consolidate her sense of self through time.

Blanchot suggests that what he calls the death of the self would be in the form of radical passivity, where a person would become anonymous and outside of the dialectical language of you and I. He writes: "But when the Other is no longer the remote, but the neighbor whose proximity weighs upon me to the point of opening me to the radical passivity of the self, then subjectivity falls in its turn outside of being" (Blanchot 1995, p. 24). There is an outside of being in passivity that would allow for the ceasing of the threat of disaster, the ceasing of the Other's threat on the subject, but there would be no subject to experience the lack of threat. In an interview, Robertson explains how filming her compulsive and ineffective behaviors actually aided her in the cessation of those very habits. Capturing her multiple subjectivities in images and sound, Robertson would typically wait a year before even looking at what she had filmed. She gave herself a sort of passive reflectivity. Robertson allowed herself to be the object of filmic documentation, while also creating a diary behind the camera. Her apologizing and its inherent catastrophizing speaks to the multiple selves present, which were created by her past fits and misfits. Her ghostly addresses toward the camera and haunting post-production sound give added interpretations of herself from multiple sources. As the self is made up of Other interpretations, Robertson saves these multiple selves on a film strip. Multiplicity on film is shown to be a strategy in gaining possession over the Others who define an individual. This strategy for gaining agency, this consolidation of multiplicity, subverts the pejorative psychological notion of a divided self into a productive strategy for coping with mental disability.

Robertson allowed the hauntings of the catastrophe to come back, and film gave her a way to approach her ghosts outside of herself. In a 1983 film by Ken McMullen titled Ghost Dance, Derrida states: "Cinema is the art of ghosts. A battle of phantoms ... It's the art of allowing ghosts to come back" (Lippit 2012, p. 94). Robertson's ghosts reemerge in the film so that she can approach them instead of pushing them away, as is the process in so much of western psychology and psychiatry. As Blanchot states: "He who criticizes or thrusts the game away, has already entered into the game" (Blanchot 1995, p. 10). Pushing away is only to make contact with the very thing we are trying to avoid, which perpetuates the effect that we would rather diminish. Robertson's process of reflecting on her images through voiceover allows her to approach her catastrophic thinking and the ghostly threat to her subjectivity. She is not declaring mastery over her mental disability, but instead learning to live with it. She is learning to live with ghosts. She reaches passivity when the self is finally outside herself on the film strip or in the sound recording. In writing on Robertson, Lisa Blackman describes how she disperses herself through machines (Blackman 2014, p. 7). When asked in an interview about her openness with her hospitalizations, Robertson emphatically states: "Well I've got to be! Otherwise as 
Kate Millett says, you're a ghost in the closet" (MacDonald 2014, p. 25). Robertson brings the disasters that haunt in advance into the light to be inspected. Her catastrophizing, the threat of the Other, is put under a microscope and highlighted through Robertson's use of shifting temporalities and ghostly sound sync. Robertson has found a way to live with ghosts and breach the bounds of psychology and selfhood by displaying her ghosts for herself and audiences instead of forever fighting them off.

In fact, Robertson shares much about her identity through her apologizing. The apologies reveal that she is concerned with healthy eating and with her weight. Her obsession with finding a husband or her apologizing for lying in bed all day offer information, such as the fact that she is a cis-gendered, heterosexual woman whose mental disability interferes with school, family, friends, and work. She expresses the fact that she loves filmmaking when we hear her apologize for returning the camera back late so many times. The specificity of her identity as a white, middle-class woman with access to psychological and psychiatric services, but also a survivor of those services, reveals her misfitting as much as her misfitting reveals her identity. All these details support Garland-Thomson's claim that misfitting and identity are co-constituting. Misfittings shape our identity, but our identity also determines our fits and misfits. Robertson's apologies are a way of exposing the misfitting that comes with her identity in a time before the Americans with Disabilities Act and a time only two decades after a mass movement for deinstitutionalization in the United States. In addition to expressing these particularities, Apologies exposes an effective practice that Robertson has devised for dealing with her mental disability. Although Robertson never directly attempts to reference or speak to the history of medical documentation, the undeniable need to write out her disability in filmic form mixes genres of documentation and diary to challenge established codes of psychological interpretation. Apologies cites the photographic histories of hysteric and seizure patients, but it is also highly premonitory of the future of psychology.

During the same years that Robertson was making Apologies, two researchers in psychology developed new therapies that continued and extended the practice of cognitive behavior therapy. These two innovations in psychology, acceptance and commitment therapy (ACT) and dialectical behavior therapy (DBT), were developed in the late 1980s. DBT was specifically developed in response to patients who were chronically suicidal, unresponsive to the practices of CBT, and considered incurable. What connects these two therapies to Robertson's approach is their concentration on radical acceptance. Marsha Linehan, the creator of DBT, describes radical acceptance as not fostering an agreement with a situation, but an acceptance that a situation exists (Linehan 2015, pp. 342-43). It is the not pushing away or getting involved in "the game" that Blanchot identifies. It allows the existence of even what is painful without adding suffering. Robertson's practice foretells the importance and usefulness of these new innovations in the research of psychology. In Robertson's case, it is a matter of recognizing the voices or the impulses and greeting them in their spectral form. It is a matter of bringing all temporalities into the continuous present of the diary form through crosscuts, voiceover, or post-production lip-synching. Marsha Linehan and others at this time realized that for suicidal patients, psychology was only one new voice, one new self for the patients to try to fit within their identity. ${ }^{4}$ Robertson incorporates these voices in her multiple subjectivities through film and sound. She captures them for later reflection. Robertson documents herself in her films, and by association, she documents Others through speaking them herself, by speaking the socially formative roles that she plays as a woman, a daughter, a student, an aunt, a patient, etc. She creates a meeting point for these different moments through the structuring of her multimedia. The film slowly builds a continuous present by haunting it with fears from the past and worries for the future, which is mirrored by the gradual conflation of different images and sounds. Robertson's multiple subjective views come to occupy the same space through spectral techniques of crosscutting and her mixture of voiceover and

4 This is perceived from the fact that the dialectic in DBT refers to the idea that patients are both, at the same time, fine as they are and they can also benefit from change. The necessity of validating patients stems from the fact that not living up to the values in psychological discourse can add to patients' fear, shame, or guilt. 
lip-synching. It is through these spectral filmic techniques that the spectrum of mental diversity and mental disability becomes knowable. The fragments of celluloid, strewn together to merge future and past in the diary's continuous present, create a dialogue mirroring the temporality that Robertson speaks through her catastrophic apologies.

Funding: This research received no external funding.

Conflicts of Interest: The author declares no conflict of interest.

\section{References}

Agamben, Giorgio. 2000. Notes on Gesture. In Means without Ends: Notes on Politics. Translated by Vincenzo Binetti, and Cesare Casarino. Minneapolis: University of Minnesota Press.

Alford, Brad A., and Aaron Temkin Beck. 1997. The Integrative Power of Cognitive Therapy. New York: The Guilford Press.

Beck, Aaron Temkin. 1976. Cognitive Therapy and the Emotional Disorders. New York: New American Library.

Beck, Judith S. 1995. Cognitive Therapy: Basics and Beyond. New York: Guilford Press.

Beck, Aaron Temkin, and Resham Gellatly. 2016. Catastrophic Thinking: A Transdiagnostic Process across Psychiatric Disorders. Cognitive Therapy and Research 40: 441-52.

Blackman, Lisa. 2014. The Dissociation of Anxiety. In Five Year Diary, Anne Charlotte Robertson. Edited by Benjamin Cook and Bárbara Rodríguez Muñoz. London: LUX, pp. 4-9.

Blanchot, Maurice. 1995. The Writing of the Disaster. Translated by Ann Smock. Lincoln: University of Nebraska Press.

Cartwright, Lisa. 1995. Screening the Body: Tracing Medicine's Visual Culture. Minneapolis: University of Minnesota Press.

Culley, Margo. 1985. A Day at a Time: The Diary Literature of American Women from 1764 to the Present. New York: City University of New York.

Dargis, Manohla, and Anthony Oliver Scott. 2013. Scrutinizing nature, sorrow and oneself with a subjective lens. The New York Times, October 2.

Derrida, Jacques. 1982. Of an Apocalyptic Tone Recently Adopted in Philosophy. Translated by John P. Leavey, Jr. Semeia 23: 63-97.

Derrida, Jacques. 1994. Specters of Marx: The State of the Debt, the Work of Mourning, $\mathcal{E}$ the New International. Translated by Peggy Kamuf. New York: Routledge Press.

Ellis, Albert. 1975. Reason and Emotion in Psychotherapy. New York: L. Stuart.

Garland-Thomson, Rosemarie. 2011. Misfit: A Feminist Materialist Disability Concept. Hypatia 26: 591-609. [CrossRef]

Gilman, Sander. 1982. Seeing the Insane. Lincoln: University of Nebraska Press.

Hall, Alice, and Tobin Siebers, eds. 2015. Disability and Visual Culture. Journal of Literary \& Cultural Disability Studies 9: $239-46$.

Linehan, Marsha M. 2015. DBT Skills Training Handouts and Worksheets. New York: The Guilford Press.

Lippit, Akira Mizuta. 2012. Ex-Cinema: From a Theory of Experimental Film and Video. Berkeley: University of California Press.

MacDonald, Scott. 2005. Avant-Gardens. In Women E Experimental Filmmaking. Edited by Jean Petrolle and Virginia Wright Wexman. Chicago: University of Illinois Press, pp. 203-37.

MacDonald, Shana. 2007. Carolee Schneemann's Fuses as Erotic Self-Portraiture. CineAction 2007: 67-71.

MacDonald, Scott. 2014. Interview. In Five Year Diary, Anne Charlotte Robertson. Edited by Benjamin Cook and Bárbara Rodríguez Muñoz. London: LUX, pp. 10-16, 25-37.

OED Online. 2018. Catastrophe, Etymology. Oxford: Oxford University Press.

Price, Margaret. 2013. Defining Mental Disability. In The Disability Studies Reader. Edited by Lennard J. Davis. New York: Routledge Press, pp. 298-307.

(C) 2019 by the author. Licensee MDPI, Basel, Switzerland. This article is an open access article distributed under the terms and conditions of the Creative Commons Attribution (CC BY) license (http://creativecommons.org/licenses/by/4.0/). 